\title{
MATHEMATICAL REPRESENTATION BASED ON PERSONALITY TYPES
}

\author{
Sitti Zuhaerah Thalhah ${ }^{1}$, Thamrin Tayeb ${ }^{2}$, Sumardin Raupu ${ }^{3}$, \\ Dwi Risky Arifanti ${ }^{4}$ \\ 1,3,4 IAIN Palopo, ${ }^{2}$ UIN Alauddin Makassar \\ 1,3,4Jl. Agatis, Balandai, Kota Palopo, 2Jl. H.M. Yasin Limpo No. 36 Romangpolong \\ Email: hera@iainpalopo.ac.id ${ }^{1}$, thamrin.tayeb@uin-alauddin.ac.id ${ }^{2}$, \\ sumardin_aldhy@iainpalopo.ac.id ${ }^{3}$, dwiriskyarifanti@gmail.com ${ }^{4}$
}

\begin{abstract}
:
This study aims at describing the mathematical representation of students with Sanguine, Choleric, Melancholic and Phlegmatic personality types in solving linear program problems. The instrument used was a personality test adapted from the Personality Plus book by Florence Litteur. The data were collected by applying linear program problems to the main subjects that represent each personality type. The results of Sanguine and Melancholy students only represented three indicators, the problem were not represented in the form of diagrams, graphs, tables or drawings, while, the Choleric and phlegmatic students represented problems in four indicators. Another finding, the sanguine students answered all the questions correctly but did not make the conclusions. The Choleric and melancholy students were less focus on the calculation process so there were some answers incorrectly, while all phlegmatic students answered incorrectly.
\end{abstract}

\begin{abstract}
Abstrak:
Penelitian ini bertujuan untuk mendeskripsikan representasi matematis mahasiswa bertipe kepribadian sanguinis, korelis, melankolis dan phlegmatis dalam menyelesaian masalah program linier. Jenis penelitian ini adalah penelitian kualitatif. Adapun instrumen yang digunakan adalah tes kepribadian yang diduplikasi dari buku Personality Plus karya Florence Litteur, lembar tes kemampuan representasi matematis dan wawancara. Data dikumpulkan dengan memberikan masalah program linier kepada subjek utama yang mewakili masing-masing tipe kepribadian, kemudian dianalisis berdasarkan indikator representasi matematis. Hasil analisis yang diperoleh, yaitu mahasiswa sanguinis dan melankolis hanya merepresentasikan tiga indikator, masalah tidak direpresentasikan dalam bentuk diagram, grafik, table atau gambar, sedangkan mahasiswa korelis dan phlegmatis merepresentasikan masalah dalam empat indikator. Temuan lain, mahasiswa sanguinis menjawab semua soal dengan benar namun tidak melakukan penarikan kesimpulan. Mahasiswa korelis dan melankolis kurang teliti dalam melakukan proses perhitungan sehingga ada soal yang dijawab salah, sedangkan mahasiswa phlegmatis semua soal dijawab salah.
\end{abstract}

\section{Keywords:}

Mathematical Representation, Personality Types, Linear Program

How to Cite: Thalhah, S., Z., Tayeb, T., Raupu, S., \& Arifanti, D., R. (2020). Mathematical Representation Based on Personality Types. Lentera Pendidikan : Jurnal Ilmu Tarbiyah dan Keguruan, 23(1), 141-157. https://doi.org/10.24252/lp.2020v23n1i12.

\section{INTRODUCTION}

Mathematical representation of the students is the ability to describe, translate, and reveal in order to create models from ideas or mathematics concepts and relationships among them in a variety of new mathematical forms. It showed that the use of 
representations contributes greatly to form understanding concepts. Astuti (2017) revealed that students as a candidate of math teacher should have a good representation ability to find out the way of mathematical idea that can be represented to facilitate his students understanding the idea well. Due to the importance of these capabilities, the learning process in the classroom needs to be designed to facilitate the development of mathematical representation capabilities (Rakungti, 2013).

Rahmawatia, Purwanto, Hidayantoa, Rahmad, \& Anwar (2017) stated about the importance of mathematical representation, she argues that representation is an important process in learning to develop and optimize students' thinking skills, which becomes a process of construction and abstraction of mathematical. Generally, mathematical representation is the expression of mathematical ideas as tools to find solutions (Feriyanto, 2020). Representation itself is defined as a model, form or expression of mathematical idea that represented the situation or problem in order to facilitate or find the solution (Siregar \& Harahap, 2019). Kohl \& Noah's stated that representation is a must have ability to interpret and apply various concepts in solving the problems appropriately. Jeniver argues that representation is one of psychology concept used in mathematics education to explain some important phenomena about the way of students think (Surya \& Istiawati, 2016).

NCTM confirms that the ability of mathematical representation is very important for students to have, it stated that Representation is acentralof mathematics study. Students can develop and deepen their understanding of mathematical concepts and relationships as they create, compare, and use various representations. Goldin in Widakdo (2017) believed that students use representations as tools to support their mathematical understanding by constructing abstract idea into concrete idea through logical thinking because representation is a sign or signs configuration, characters, or objects which mark and configuration to stand, describe, or represent something. Representation is the most fundamental way to understand mathematics ideas as well as a tool to support mathematical understanding by building abstract ideas that are concrete through logical thinking. Syahputra \& Marpaung (2016: 261) argued that representation had risen by the students are expressions of ideas or the ideas of mathematical shown students in efforts to find a solution to the problem at hand. The meaning of that sentence showed that the representation presented by the students is a form of expression of mathematical ideas shown to find a solution of the problems faced.

In solving problem related to the student's representation, it should fulfill three operational forms as follows:

Table 1. Forms of Operational Representation

\begin{tabular}{cl}
\hline Representation & \multicolumn{1}{c}{ Operational Forms } \\
\hline Visual & 1) Representing data or information from a representation to a \\
representation & diagram, chart, or table representation \\
$\begin{array}{c}\text { a) diagrams, } \\
\text { tables, or graphs }\end{array}$ & 2) Using visual representation to resolve the problem. \\
\hline
\end{tabular}




\begin{tabular}{|c|c|}
\hline b) Picture & $\begin{array}{l}\text { 1) Creating an image of geometric patterns. } \\
\text { 2) Creating images to clarify problems and facilitate completion. }\end{array}$ \\
\hline $\begin{array}{l}\text { Mathematical } \\
\text { equations or } \\
\text { expressions }\end{array}$ & $\begin{array}{l}\text { 1) Creating a mathematical equation or model of another } \\
\text { representation given. } \\
\text { 2) Make a conjtour of a number pattern. } \\
\text { 3) Solving problems with involving mathematical expressions. }\end{array}$ \\
\hline $\begin{array}{l}\text { Words or Written } \\
\text { Text }\end{array}$ & $\begin{array}{l}\text { 1) Creating a data-driven problem situation or representation } \\
\text { given } \\
\text { 2) Writing the interpretation of a representation } \\
\text { 3) Write down the math problem solving steps with words } \\
\text { 4) Composing a story that corresponds to a representation } \\
\text { presented } \\
\text { 5) Answering questions using written words or text }\end{array}$ \\
\hline
\end{tabular}

(Oktavianti, 2014)

Each student has different ways to solve linear programs problem because they have different characteristics or personalities. The personality types of Hippocrates-Galenus in the study of psychological sciences are Sanguine, Melancholy, Choleric and Phlegmatic (Oktavianti, 2014). Ikhwan, Farid, Rohmad, \& Sham (2019: 163) argued that personality is a character which means behaviour possessed by a person in order to be inherent and caused by environmental influences. John and Srivastava in Kim \& MacCann (2017: 2) added that personality is a set of characteristics, which underlies an individual's cognition, emotions, and behaviour that distinguishes one individual from another. Eventhough many people have dominant personality type, some of them have two or more types, and nobodyhas a dominant type with no aspects of other types (Harlow, Harrison, Justason, Meyertholen, \& Wilson, 2017).

There is a wide range of personality theory approaches, but the most widely used and applied ones are the personality type theories introduced by Hippocrates that divide personality types into four, namely type of Choleric, Sanguine, Melancholic, and Phlegmatic (Sari \& Shabr, 2016). Based on Galenus, Choleric has a distinctive trait of life, immense vigor, great fighting power, flammable heart, and optimism. Meanwhile, a melancholy has the nature of disappointment, small fighting power, grim and pessimistic. Typical phlegmatic properties do not like to rush (calm, calm), ineffable and faithful. A sanguine has a distinctive nature of life, easy to change, friendly, agile Act but also a crotchety stop (Sujanto, Lubis, \& Hadi, 2004: 10). The type of personality in this study is the type of personality refers to Hippocrates-Gelanus type Sanguine, melancholy, Choleric and Phlegmatic. If educators do not know their students' personality, it will impede learning process that caused not achieving the maximum goals and outcomes, Lecturers are not proficient in teaching, and learners are unable to gain successfulness. Likewise, if a lecturer does not know the ability of students' mathematical representation, that caused lecturer is unable to measure the success of the learning process refers to the understanding of mathematical Concepts .

Oktaviyanthi \& Supriyani (2017), conducted the research about The Mathematical 
Representation of a Personality Type Student Sanguinis. They concluded that there are four technical indicators used and only three indicators done by the subject. The difference with this study is to describe the mathematical representation based on four personality types, it is not just the sanguine type but the other three types of melancholy, Choleric, and Phlegmatic. Handayani (2016) conducted the research entitled Analysis of Mathematical Representation Ability in PBL Model reviewed from the Student Personality Type, it is concluded that the use of the PBL Model achieved the classic submission on the representation aspect of Guardian, Idealist and Artisan personality types. Unlike the research the type of personality examined focuses on the personality types of Sanguine, Melancholy, Choleric, and Phlegmatic. Supriyati (2016) conducted the research about the Description of Ability to understand mathematical concepts of class VII SMP Negeri 2 Rakit (it is reviewed from the personality type of typologies Hippocrates-Gelanus) concluded that, students with sanguine personality types with their cluttered and passionate nature have a reasonably good concept of understanding, students with corelic and phlegmatic personality types with consistent nature have a good understanding of the concept , and students with a melancholy personality with their analytical and detailed nature have good concept comprehension skills. The difference with this research is describing the ability of mathematical representation.

Therefore, the researcher is interested in researching about the mathematical representation of the students of IAIN Palopo mathematics based on the personality types of Sangune, Melancholic, Choleric, and Phlegmatic so that in the future lecturers can design the learning process to optimize the skills that the students have.

\section{RESEARCH METHOD}

This research is qualitative research with explorative descriptive approach to find out the ability intensively and comprehensively in order to student representations of the personality types; Sanguinis, Choleric, melancholy, and phlegmatic in solving mathematical problems of linear programs. The subject was first semester students of Mathematics Education who took Linear Program course Batch 2018-2019.

The selection of the subject is conducted with purposive sampling technique which focused on one student as the main subject from each group refers to the most personality type. The mapping the personality type result 3 classes (110 students) candidate for research subject is, there are 31 students as a candidate subject to sanguinis personality types, 12 students as candidate subjects for the Choleric personality type, 25 students as candidates for the subject of melancholy personality type, and 31 students as the subject candidate for Phegmatic personality type. The instruments in this study are: (1) Personality Tests based on the book of Personality Plus by Florence Litteur, (2) Test Sheet of the ability of a mathematical representation of the course material of the linear Program is organized and arranged based on the basic competencies in the course curriculum. The mathematical representation Ability test consist of two-essay problem in order to find out the skills of mathematical representation of students, (3) The interview contains the 
questions of researchers to uncover the student's mathematical presentation in resolving the questions given.

The Research started giving each of them (four students as the main subject) with two questions a linear program. Each student answers the same question. Researchers then conducted interviews on the main subject regarding to the written answer. Furthermore, the resultswere collected and analyzed through technical indicators of mathematical representation by Oktavianti (2014), namely: (1) Presenting data/information of an issue in the form of diagrams, graphs, tables or drawings; (2) Creating the equation/mathematical model of the given problem; (3) Creating a problem situation based on known data/information; and (4) Writing down the completed steps.

The following modifications to data analysis and interpretation based on L. R Gay are to identify data collection from the results of a personality and the test of mathematical representation capability. Every indicator of mathematical representations that appeared to be coded, asking main questions with a subject interview, creating a review organizational by grouping students by personality type, presenting findings in tables form, and suggesting and identifying what has not been researched. Data interpretation is done by linking analysis results to the theory, contacting and reviewing relevant theories, distinguishing the results of previous analyses, linking findings with personal experience, describing the self-opinion of the results obtained.

Researcher encodes the results of student work as S1 for subjects with Sanguinis personality types, S2 for subjects with a Choleric personality type, S3 for subjects with melancholy personality type, and S4 for subjects with phlegmatic personality types. Researcher searched for two linear program issues, and then it compared the results of the two troubleshooting steps that were performed, with the interview notes of each subject.

\section{FINDING AND DISCUSSION}

\section{Subjects with Sanguinis Personality Types $\left(S_{1}\right)$}

The following result showedthe interview data with Sanguinist personality type (S1) along with the work result data from the problem solving the linear program provided and analyzed based on the mathematical representation indicators suggested by Oktavianti (2014). The data are presented in the following table:

Table 2. Interview Data of Subject S1 based on Mathematical Representation

\begin{tabular}{cll}
\hline $\begin{array}{c}\text { Num } \\
\text { ber }\end{array}$ & \multicolumn{1}{c}{$\begin{array}{c}\text { Indicators of } \\
\text { Mathematical } \\
\text { Representation }\end{array}$} & \\
\hline & $\begin{array}{l}\text { Representing the } \\
\text { data/information of an }\end{array}$ & $\begin{array}{l}\text { R: What do you understand about this problem? } \\
\text { S: Actually, I want to look for maximum profit from }\end{array}$ \\
tion & $\begin{array}{l}\text { issue in the form of } \\
\text { diagrams, graphs, tables } \\
\text { or drawings (A1). }\end{array}$ & $\begin{array}{l}\text { the sale of dress and T-shirt. The material used are } \\
\text { cotton, silk and wool. Cotton is about 16 meter, } 11 \\
\text { meter silk, 15 meter wool. Continue to have } 2\end{array}$
\end{tabular}

MATHEMATICAL REPRESENTATION BASED ON PERSONALITY (SITTI Z. T., THAMRIN T., SUMARDIN R., \& DWI R. A.) 145 
fatness, same dress shirt (while she marking the problem)

R: Why do not you make a table?

$S$ : I think there is no need for that, because I had the intention of wasting time (smiling).

Create equations or the mathematical model of the given problem (A2).
R: Then, how to solve that problem?

S: Firstly, I specified the variable, the function of the same purpose which constraint function (while he is writing).

\section{A2}

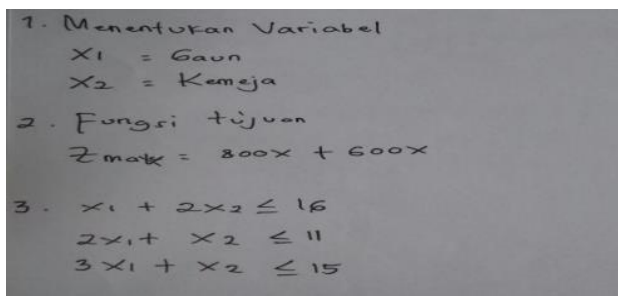

Creates problem situation based on the data/information (A 3.1).

S: If it is already created function purpose equal function constraints live sought completion by the graph/chart method. Because it is asked about the maximum problem, so I will select feasible point If the substitution in $\mathrm{Z}$ most-high value.

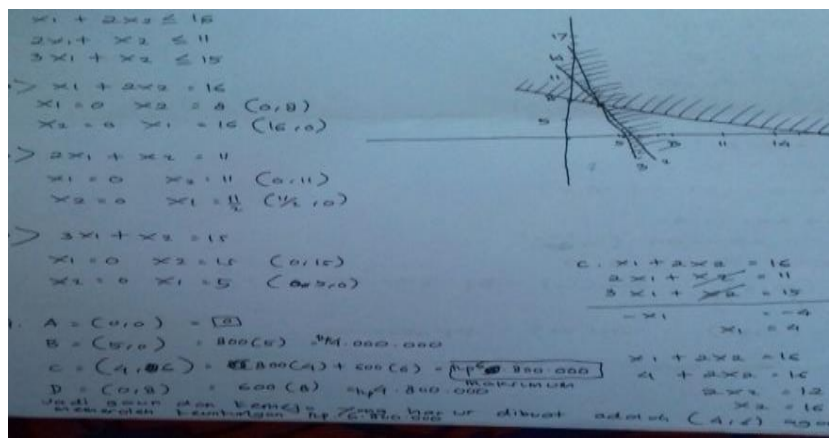

A3.1

Write down the R: Why do not you directly draw the chart alone? completion steps (A 3.2). S: I cannot do that. I should make the purpose of the function then I can draw its chart.

A3.2

Representing the

Ques data/information of an

tion issue in the form of

2 diagrams, graphs, tables or drawings (A1).
S: I do not need to make the table.

A1(tidakmuncul)

A1 (not appearing) 
Create a mathematical equation or model of the given problem (A 3.1).

Create problem situation based on the data/information
S: Along with Question 1, I need to specify variable, the function of the same purpose and constraint function.

A3.1

S: This is the minimum case, so I would like to draw the chart in search feasible point that the reply is substituted in $\mathrm{Z}$ the lowest value.

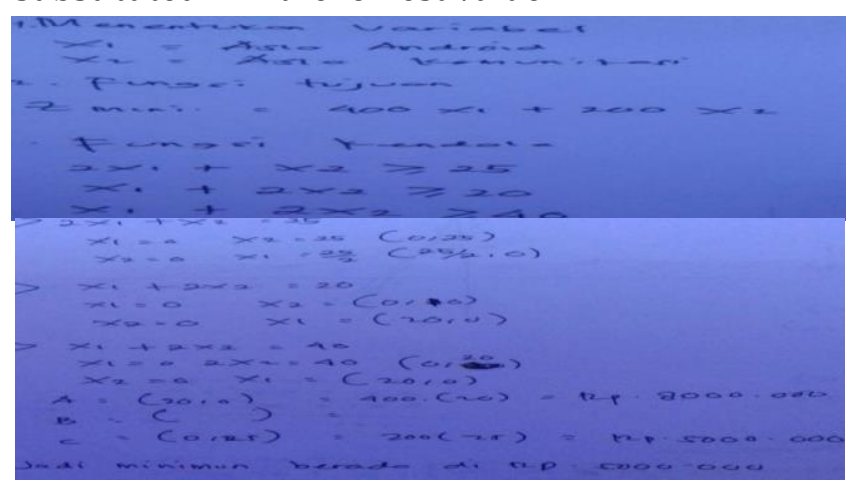

A3.1

Write down the

R: Did you solve the problem systematically?

completion steps (A 3.2). S: Yes, I did, you can see the picture, I started from step 1 to step 4.

A3.2

Based on table 2, Having been traced with two problems of linear programs on the subject S1, it then compared with the results of the two troubleshooting steps with the interview note, it showed that: (1) Subject S1 does not review the information in the tables form, but the subject is able to understand the problem given correctly. It can be seen from the results of the work subject S1 that does not present the data/information of an issue in the form of diagrams, graphs, tables or images, but when the interview subject can mention correctly the completion steps of the problem given; (2) The subject S1 may create a mathematical equation or model of the given problem. It is seen when the subject writes directly the mathematical model without creating the table; (3) the subject S1 creates a problem situation based on the known data/information and provides the correct settlement answer; and (4) the subject S1 writes the resolution measures performed systematically which can be seen from the solution. However, in question No. 2 the subject of $\mathrm{S} 1$ does not give conclusions from the situation.

The student with sanguist personality type based on mathematical representation is capable of making mathematical equations or expressions and creating written words or text to interpret the completion of mathematical problems. Amalia \& Snani (2019) had the same argument with the statement, they stated that the ability of a sanguinis type based on mathematical representation is able to create mathematical models or mathematical equations and communicate the mathematical representation. However, the students with sanguinis personality types are underprivileged to perform mathematical reprentation because they can not do a visual representation 


\section{Subjects with a CholericPersonality Type (S2)}

The following result showed the interview data with Choleric personality type (S1) along with the work result data from the problem solving the linear program provided and analyzed based on the mathematical representation indicators suggested by Oktavianti (2014). The data are presented in the following table:

Table 3. The Result of Interview Data of S2 based on The Indicators of Mathematical Representation

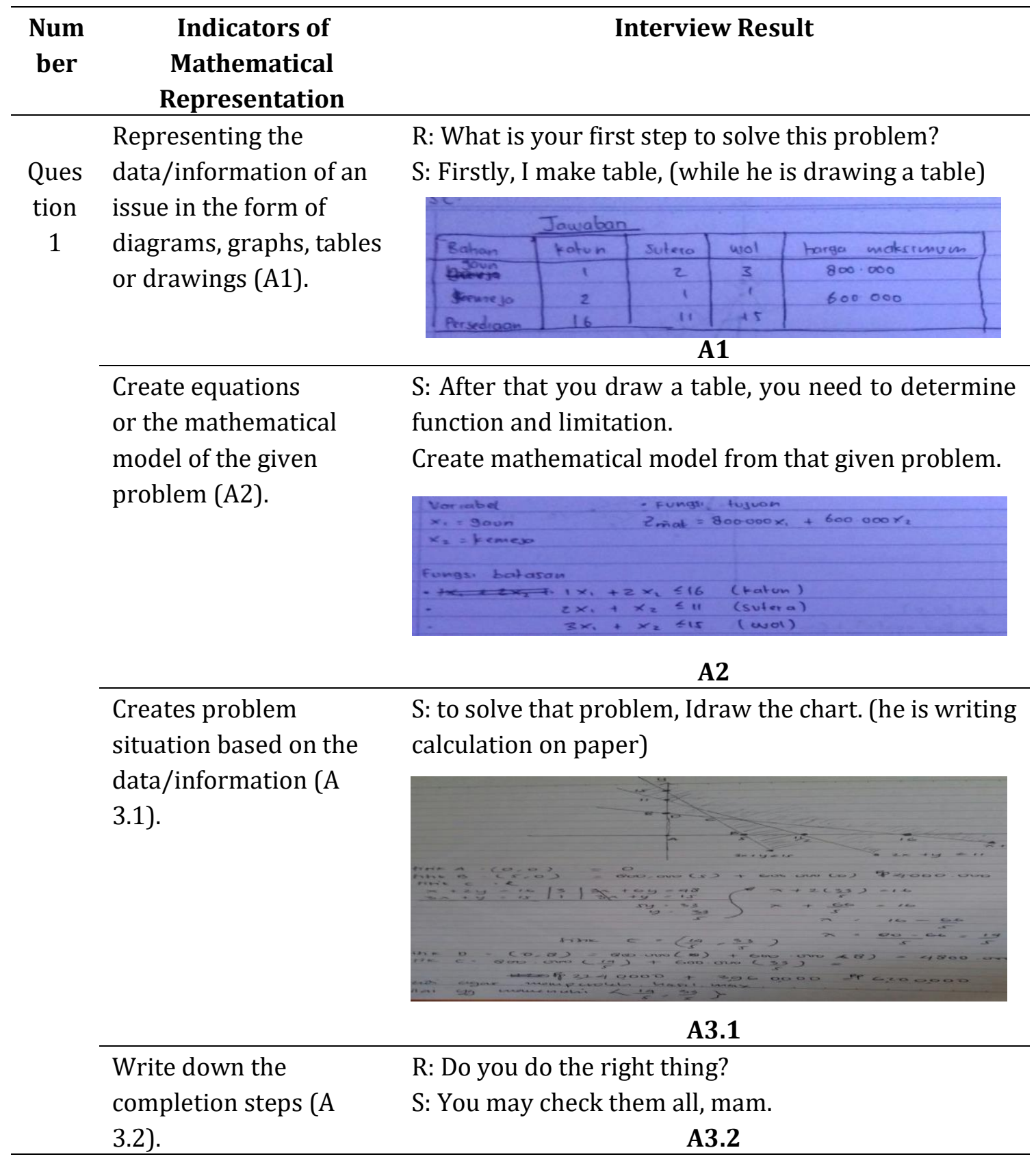




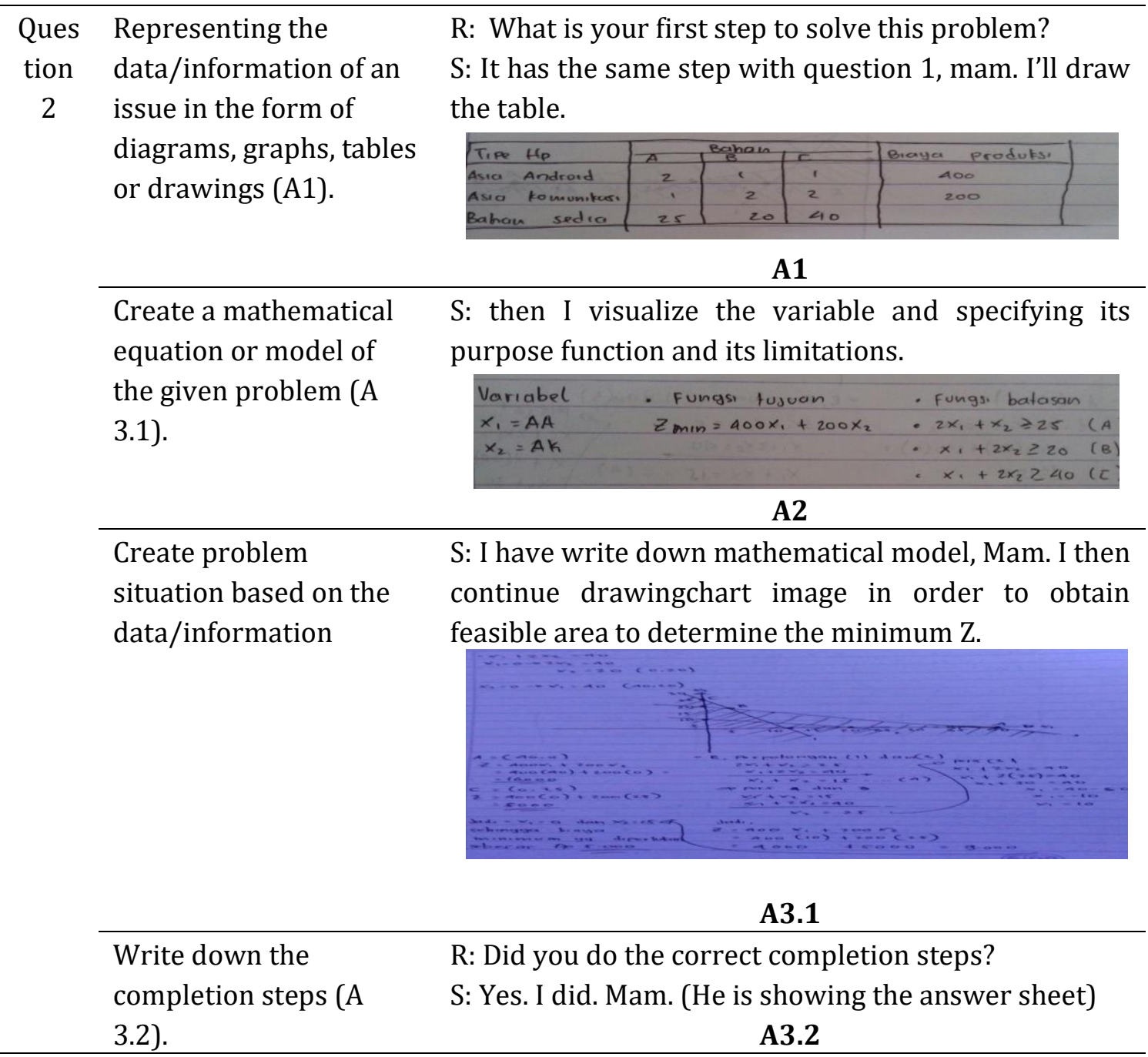

Based on table 3 above, Having been traced with two issues of linear programs on the subject of S2, it then compared with the results of the two troubleshooting steps with the interview note, it showed that: (1) The S2 subject can represent data/information of an issue in the form of a table. It is shown when the researcher interviews the S2 subject about the initial step to be done in resolving the problem, then the subject responds by creating a table first; (2) Subject S2 can create mathematical models of the problems given. This is apparent when the subject is reseparating the X1 and X2 variables and then the destination function and the limit; (3) Subject S2 can create a problem situation based on the data/information that is in the matter. It is seen when the subject of drawing the graph/chart first to be able to solve the problem given, the subject also performs the calculations by writing it on paper; and (4) S2 subjects may write the steps of completion. However, the problem solving that have been done by the $\mathrm{S} 2$ subject is not precisely due to an error in the calculation process.

A student with Choleric Personality type due to mathematical representation is capable of doing visual representation, making mathematical equations or expressions and creating written words or text that aims to interpret mathematical problems. Latifah 
(2018) had also argued that the Choleric type is able to express the opinion using mathematical language, but he/she can not solve the problem perfectly. Thus, the mathematical representation of the Choleric-type students already meets three indicators, but they can not resolve the problem.

\section{Subjects with Melancholy Personality Type (S3)}

The following result showed the interview data with Melancholy personality type (S3) along with the work result data from the problem solving the linear program provided and analyzed based on the mathematical representation indicators suggested by Oktavianti (2014). The data are presented in the following table:

Table 4. The Data Interview Result of S3 Subject based on Mathematical Representation

\begin{tabular}{ccc}
\hline $\begin{array}{c}\text { Num } \\
\text { ber }\end{array}$ & $\begin{array}{c}\text { Indicators of } \\
\text { Mathematical } \\
\text { Representation }\end{array}$ & Interview Result \\
& & \\
\hline
\end{tabular}

Quest Representing the R: What steps did you do to solve the problem?

ion 1 data/information of an S: I directly specify the variable.

issue in the form of

A1 (Not shown)

diagrams, graphs,

tables or drawings

(A1).

Create equations

Q: Once the variables are specified, I define the or the mathematical purpose function and its constraints function as well. model of the given problem (A2).

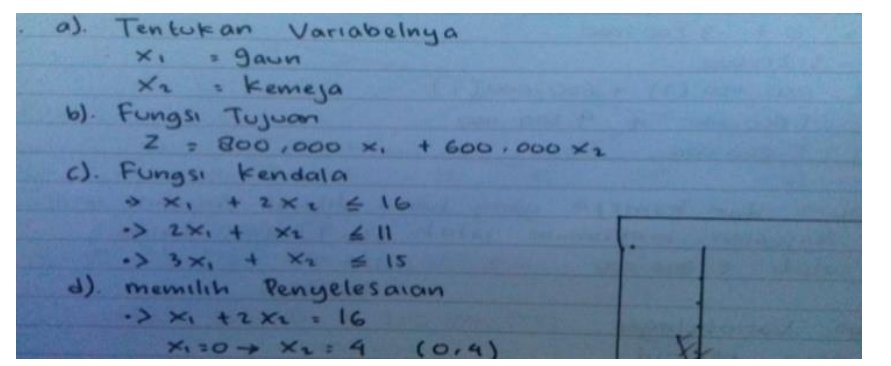

A2

Creates problem situation based on the data/information (A 3.1).
S: having been written down the mathematical model of the purpose of the function and constraints function. I draw the graphics/chart to find out the feasible area.

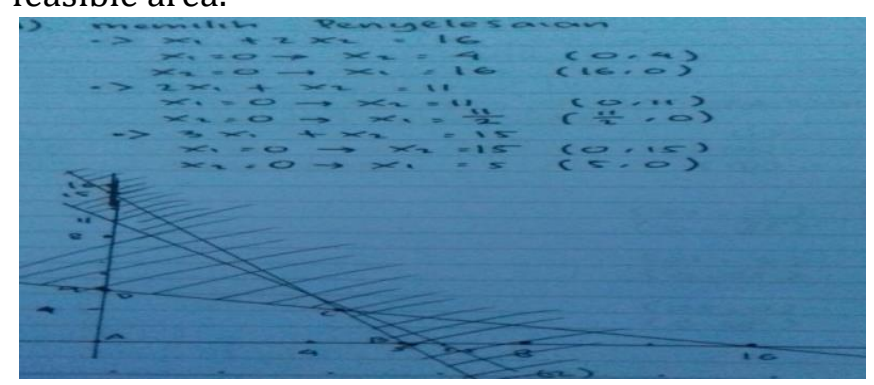




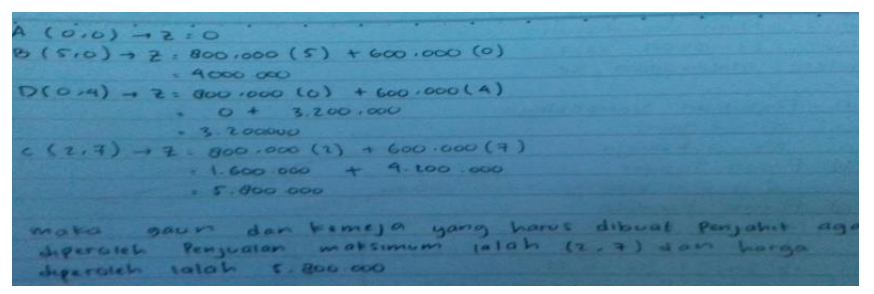

A3.1

Write down the completion steps (A 3.2).
R: Do youresolve the problem by performing some steps systematically?

S: Yes Mam. I arrange by defining variables, formulating mathematical purpose functions and constraints then drawing graphs, determining the maximum $\mathrm{Z}$ value and drawing the conclusions.

A3.2

R: Do you need to draw a table from this problem?

Representing the S: I directly draw mathematical formulations.

Quest data/information of an

ion 2 issue in the form of diagrams, graphs, tables or drawings (A1).

Create a mathematical S: For example, I illustrate my self as X1: Asia Android equation or model of the given problem $(\mathrm{A}$ 3.1). and X2: Asia communication then I try to formulate the purpose function and constraint functions.

\section{A1 (Not shown)}

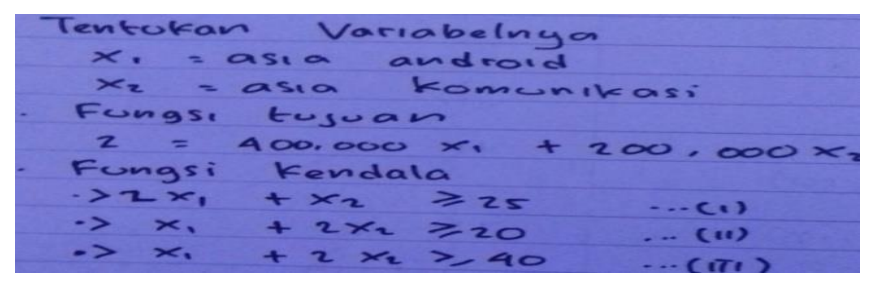

A2

Create problem

situation based on the data/information
S: I then draw the chart to define the area feasible

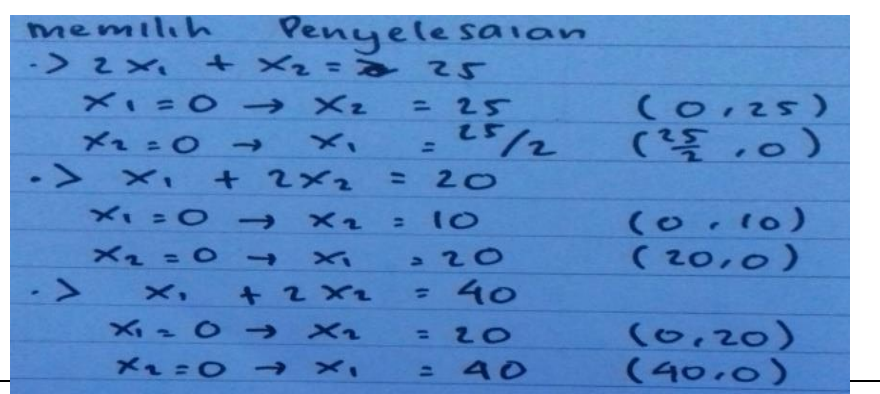




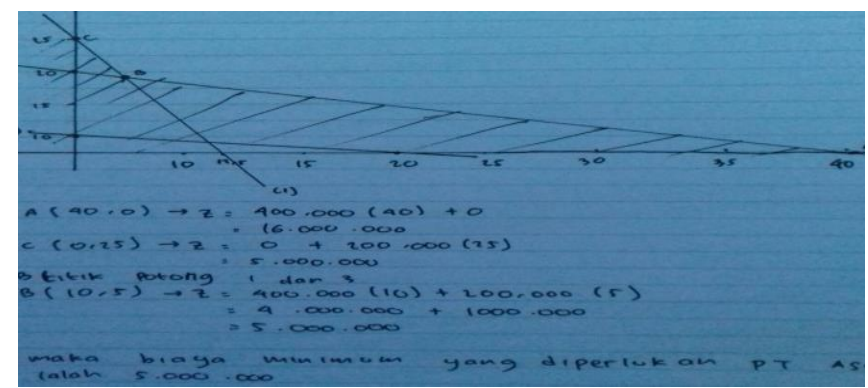

A3.1

Write down the R: Is there any solution systematically?

completion steps (A S: Yes, Mam. like this (while he is showing the answer $3.2)$. sheet)

A3.2

Based on table 4 above, having been traced with two issues of linear programs on the subject of S3, it is then compared with the results of the two troubleshooting steps with the interview note, it showed that: (1) The S3 subject does not render back data/information of an issue in the form of diagrams, graphs, tables or images. This is evident when researchers ask the subject about the initial steps taken to solve the problem of a given linear program, but the subject provides an improper response that directly determines the variable without presenting the data/information of the problem given in the form of diagrams, graphs, tables, or images; (2) The S3 subject creates a mathematical equation or model of the given problem. It is seen after the subject determines the variable, then continues by specifying the function of the destination and the function of the ride; (3) The S3 subject creates a problem situation based on the data/information that is in the matter. It was seen when the subject wrote a mathematical model of purpose function and constraint function, then described the graphics to find the feasible area; (4) The subject of S3 writes the settlement steps performed. It is evident when researchers qualified if the problem solving has been done with systematic measures, then the subject mentions the steps that done in resolving the problem of the given linear program. However, the subject of S3 will have a calculation error in question No. 1 when distributing the feasible point to the destination function.

The student with Melancholy personality type based on mathematical representation is capable of creating mathematical equations or expressions and written words or text to interpret the solving of mathematical problems. Zainab (2019) also stated that a melancholy type understands problemsand solving measures well but he/she takes too long time in finding solutions. However, the student with melancholy type is under privileged to do mathematical reprentation because he/she can not do a visual representation and slow to resolve problems. 


\section{Subjects with a Phlegmatic Personality Type (S4)}

The following result showed the interview data with a phlegmatic personality type (S4) along with the work result data from the problem solving the linear program provided and analyzed based on the mathematical representation indicators suggested by Oktavianti (2014). The data are presented in the following table:

Table 5. The Result of Data Subject Interview (S4) based on Mathematical Representation

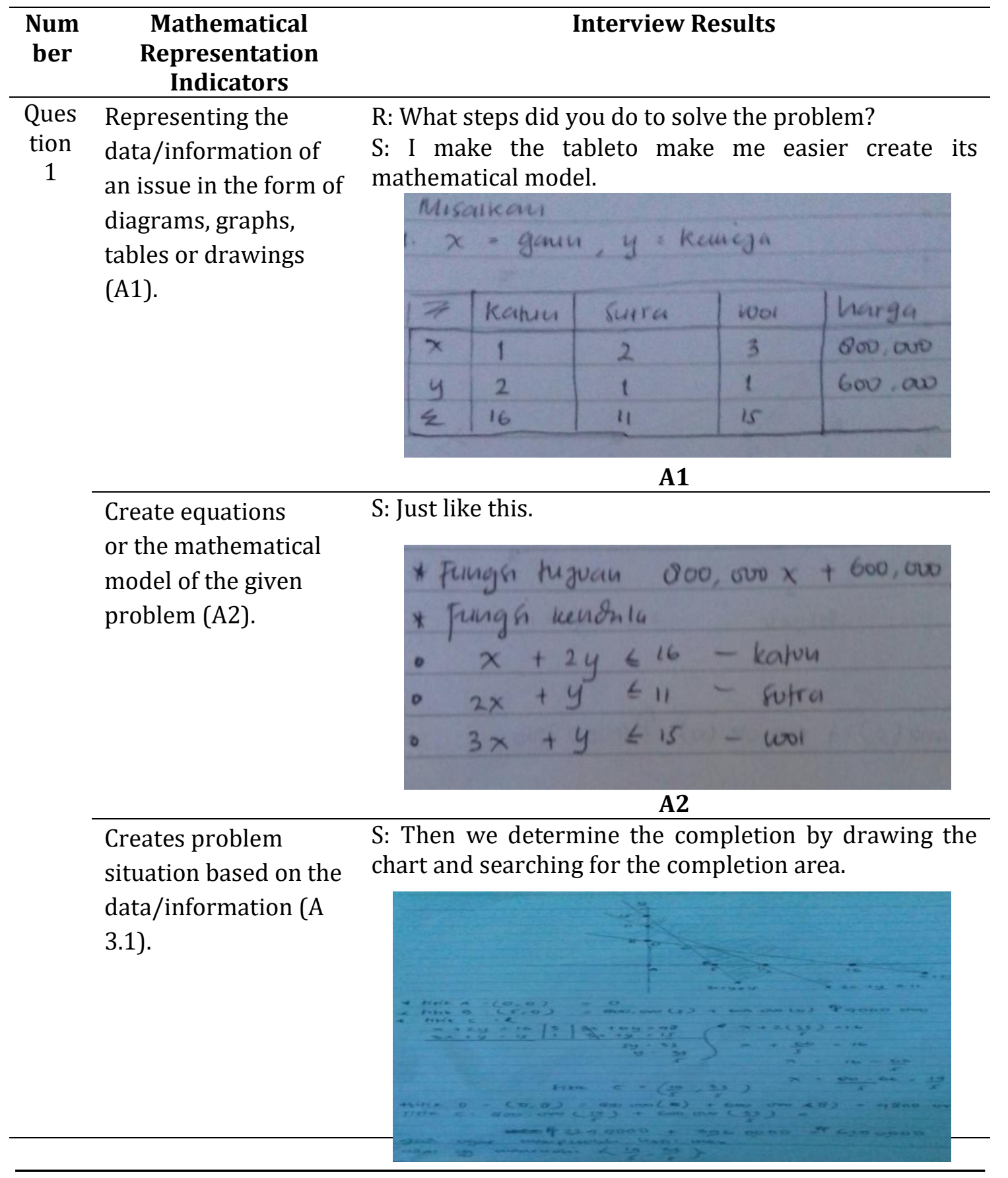




\section{A3.1}

Write down the

R: Do you resolve the problem by performing some

completion steps (A steps systematically?

3.2).

S: Yes. Mam., starting from step 1 of creating a table, Step 2 , by Specifying the goal function and constraint, Step 3 determines the completion by drawing the chart and looking for the point that resulted in the maximum purpose function. Then, I draw the conclusions.

\section{A3.2}

Soal Representing the

No.2 data/information of an issue in the form of diagrams, graphs, tables or drawings (A1).
R: In question 2, What to do first to solve the problem? $\mathrm{S}$ : it has the same way with question 1, I made the table just like this.

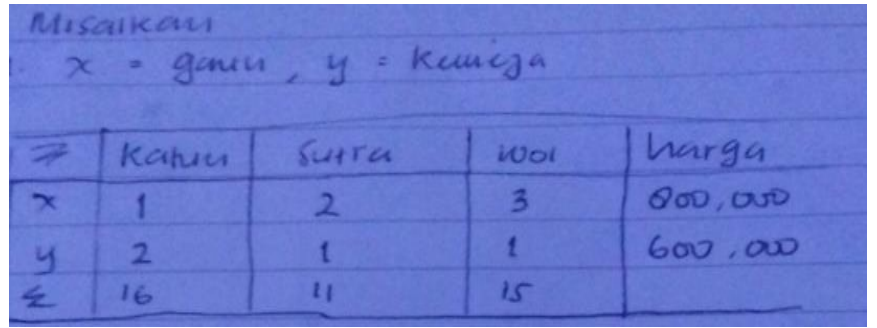

A1

Create a mathematical S: I then determine the purpose function and constraint equation or model of the given problem $(\mathrm{A}$ 3.1).

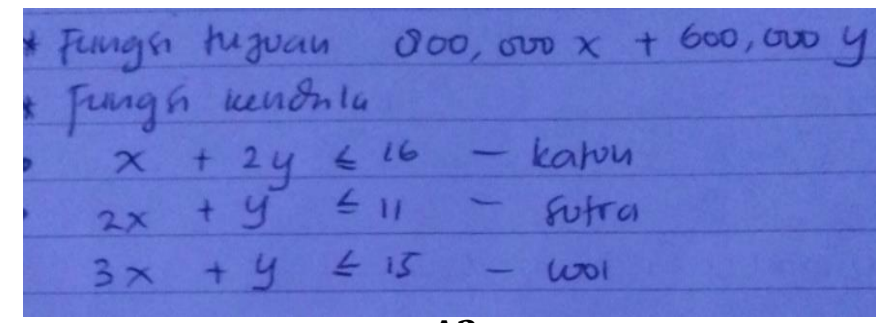

Create problem situation based on the data/information

S: Then I Continue to determine the completion by drawing the chart of Constraints function 1, 2 and 3 then I further looking for areas of completion that restrict the function of constraints

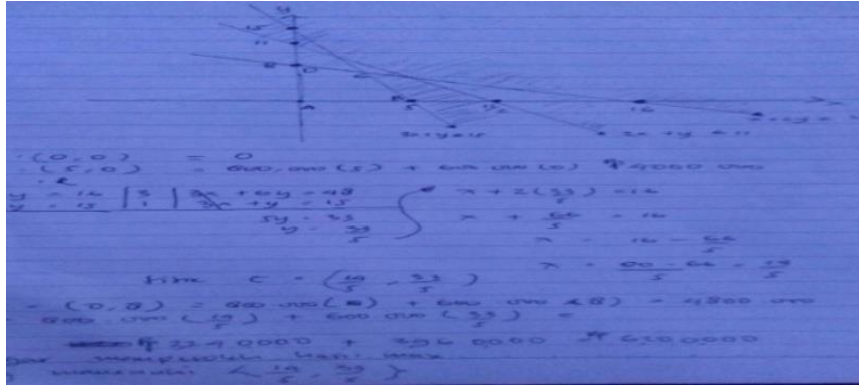

A3.1

Write down the

R: Is Question 2 conducted systematically?

completion steps (A

3.2).
S: Yes, Mam. I start from step 1 then draw the conclusion.

A3.2 
Based on table 5 above, Having been traced with two issues of linear programs on the subject of S4, it then compared with the results of the two trouble shooting steps with the interview note, it showed that: (1) Subject S4 presents back data/information of an issue in the form of diagrams, graphs, tables or images. It was seen when researchers asked the initial steps, and the subject gave a response that the initial step was to make the table easier to create the mathematical model; (2) Subject S4 makes a mathematical equation or model of the given problem. It is seen when the subject shows the purpose function and the constraint function of the given linear program problem; (3) Subject S4 Creates a problem situation based on known data/information. This is evident when the subject determines the solution to the problem of a given linear program by describing its graphics and determining the area of completion; and (4) Subject S4 writes the completion steps. It was evident when researchers asked if the problem solving measures were systematic, and then the subject stated that he had done systematic steps of completion. However, the subject of the S4 made a mistake due to lack of diligence in the calculation process in the answer to question No. 1 and No. 2.

A student with phlegmatic type based on mathematical representation is capable of doing visual representation, creating mathematical equations or expressions and written words or text to interpret mathematical problems. Fitria (2015) believed that a phlegmatic type understands question well, he/she can state the mathematical and flexible ideas in resolving problems. Thus, phlegmatic students have fulfilled three indicators, but less thorough in calculation.

\section{CONCLUSION}

Based on the results of this research, it can be concluded that: (1) The Students with Sanguist personality type based on mathematical representation fulfilled two indicators namely equations representations and mathematical expressions, words representations and written text. (2) Choleric-type students fullfilled three indicators namely visual representations, equations repsentation and mathematical expressions, words representations and written text. (3) A melancholy personality types meet two indicators namely equations representations and mathematical expressions, words representations and written text. (4) The phlegmatic-type students met three indicators, namely visual representation, equation representation and mathematical expressions, words representation and written text.

\section{REFERENCES}

Amalia, S. ., \& Snani. (2019). Representasi Matematis dalam Pembelajaran dengan Model Problem-Based Learning Berbasis Etnomatika Ditinjau dari Tipe Kepribadian. Jurnal Elemen, 5(2), 190-205. http://e-journal.hamzanwadi.ac.id/index.php/jel

Astuti, E. P. (2017). Representasi Matematis Mahasiswa Calon Guru dalam Menyelesaikan Masalah Matematika. Jurnal Tadris Matematika, 10(1), 70-82. https://doi.org/https://doi.org/10.20414/betajtm.v10i1.100 
Feriyanto, F. (2020). Analisis Kemampuan Representasi Matematis Mahasiswa dalam Menyelesaikan Soal Program Linear Ditinjau dari Perbedaan Gender. Prosiding SNP2M (Seminar Nasional Penelitian Dan Pengabdian Masyarakat) UNIM, 90-97.

Fitria, C. (2015). Profil Keterampilan berpikir kreatif dalam memecahkan masalah matematika ditinjau dari Tipe Kepribadian Sanguinis, Korelis, Melankolis, dan Plegmatis. Jurnal Ilmiah Pendidikan Matematika, 3(3), 23-32. https://doi.org/http://dx.doi.org/10.33477/mp.v6i2.666

Handayani, D. (2016). Analisis Kemampuan Representasi Matematis dalam Model PBL Ditinjau Dari Tipe Kepribadian Siswa. Digilib Unnes. http://lib.unnes.ac.id/28998

Harlow, J. J. B., Harrison, D. M., Justason, M., Meyertholen, A., \& Wilson, B. (2017). Personality Types and Student Performance in An Introductory Physics Course. Physical Review Physics Education Research, 13(2), 1-14. https://doi.org/https://doi.org/10.1103/PhysRevPhysEducRes.13.020124

Ikhwan, A., Farid, M., Rohmad, A., \& Syam, A. R. (2019). Revitalization of Islamic Education Teachers in the Development of Student Personality. Proceedings of the 1st Borobudur International Symposium on Humanities, Economics and Social Sciences, 162-165. https://doi.org/https://doi.org/10.2991/assehr.k.200529.034

Kim, L. E., \& MacCann, C. (2017). Instructor Personality MattersforStudent Evaluations:Evidence from Two Subject Areas at University. British Journal of Educational Psychology, 88(2), 1-22. https://doi.org/https://doi.org/10.1111/bjep.12205

Latifah, H. (2018). Deskripsi Kemampuan Komunikasi Matematis Siswa SMK Taman Siswa Ditinjau dari Tipe Kepribadian Tipologi Hippocrates-Galeneus. Repository Universitas Muhammdiyah Purwokerto.

Oktavianti, R. (2014). Profil Daya Matematis Siswa ditinjau dari Kecenderungan Kepribadian. Prosiding, Seminar Nasional Pendidikan Diselenggarakan STKIP Surya Tanggal 14 Februari 2014.

Oktaviyanthi, R., \& Supriyani, Y. (2017). Representasi Matematis Mahasiswa Bertipe Kepribadian Sanguinis. Jurnal Penelitian Dan Pembelajaran Matematika, 10(1), 108-114. https://doi.org/https://doi.org/10.30870/jppm.v10i1.1203

Rahmawatia, D., Purwantoa, Subanjia, Hidayantoa, E., Rahmad, \& Anwar, B. (2017). Process of Mathematical Representation Translation from Verbal into Graphic. International Electronic Journal of Mathematics Education, 12(3), 367-381.

Rakungti, N. A. (2013). Representasi Matematis. Jurnal Logaritma, 1(2), 49-61.

Sari, H., \& Shabr. (2016). Hubungan Tipe Kepribadian dengan Motivasi Belajar Pada Mahasiswa Kurikulum Berbasis Kompetensi Fakultas Keperawatan Universitas Syiah Kuala. Idea Nursing Journal, 7(2), 1-10.

Siregar, \& Harahap, H. S. S. (2019). Efektivitas Kemampuan Representasi Siswa Menggunakan Pendekatan Realistic Mathematics Education (RME) di SMA Negeri 1 Angkola Timur. Jurnal MathEdu (Mathematic Education Journal), 2(1). http://journal.ipts.ac.id/index.php/MathEdu/article/view/610

Sujanto, A., Lubis, H., \& Hadi, T. (2004). Psikologi Kepribadian. Bumi Aksara.

Supriyati. (2016). Deskripsi Kemampuan Pemahaman Konsep Matematis Siswa Kelas VII SMP Negeri 2 Rakit (Ditinjau dari Tipe Kepribadian Tipologi Hippocrates-Gelanus). Universitas Muhammadiyah Purwokerto. 
Surya, E., \& Istiawati. (2016). Mathematical Representation Ability in Private Class XI SMA YPI Dharma Budi Sidamanik. Jurnal Saung Guru, 8(2). http://jurnal.upi.edu/saungguru/view/3868

Syahputra, E., \& Marpaung, R. I. T. (2016). Students' Mathematics Representation and The Alternative Solutions. Proceedings of the 1 St Annual International Seminar on Transformative Education and Educational Leadership (AISTEEL), 260-266.

Widakdo, W. A. (2017). Mathematical Representation Ability by Using Project Based Learning on the Topic of Statistics. Journal of Physics: Conference Series. https://doi.org/https://doi.org/10.1088/1742-6596/895/1/012055

Zainab. (2019). Profil Matematika Belief Siswa dalam Menyelesaikan Masalah Matematika Ditinjaudari Tipe Kepribadian Hippocrates-Gelanus. Digilib Universitas Sunan Ampel Surabaya. 